\title{
Selametan as A Solution to the Liminality of Life During the Covid 19 Pandemic
}

\author{
Monica Cicilia Agustha ${ }^{1}$, Yusup Rogo Yuono ${ }^{2}$, Agung Dian Rengganis ${ }^{3}$, \\ Stephanus Karnadhi ${ }^{4}$, Eva Femmy Tumiwa ${ }^{5}$ \\ Satya Wacana Christian University, Sangkakala Theological School $1^{1,2,3,4,5}$ \\ \{ciciliamonica13@gmail.com¹, yusupyuono@gmail.com², agungdian14@gmail.com³, \\ stephanuskarnadhi61@outlook.com ${ }^{4}$,greisyedlvsjc@yahoo.co.id $\left.{ }^{5}\right\}$
}

\begin{abstract}
The Covid 19 pandemic has changed the earth's face along with the rest of the world's population. There are no people who are not affected by the Covid 19 virus. All governments in the world are fighting against invisible viruses. Traditional people use selametan as a means of conducting outbreaks in the region. Through a qualitative approach, with a descriptive method of analysis, it was found that selametan is implemented by traditional communities and can prevent and provide immunity and comfort for the region's people.
\end{abstract}

Keywords: Selametan; Covid 19; Ritual

\section{Introduction}

Human life is tinged with uncertainty. In uncertainty, the man often expects a helper, both from himself and outside forces, to stabilize his living conditions. Various ways are used to get through the liminal period. Of the many ways in overcoming the liminality phase, Javanese people have a unique way of coping with their liminal state.[1] Selametan is a means to bridge the condition of liminality. In his study, Clifford Geertz said that selametan is a small ceremony in the religious system. This event is usually attended by village elders, close neighbors, relatives, and core families. After the dive is complete, guests will usually be served various wet snacks (rice, side dishes, additional snacks, or pastries) or pastries (instant noodles, soy sauce, cooking oil, tomato sauce, sambal sauce) called besekan or berkat. [2]

Selametan is a ritual tradition that arises when in a liminal state in his life.[3] Javanese people do selametan when going into the liminal phase and after passing the liminal phase. Selametan is often performed to ask for blessings for the passage of his liminal period. Liminality is very diverse. It starts from the birth phase and ends in the death phase. In various phases of liminality, people in Java believe that Selametan can be used as a medium to "save" from ancestors' spirit disorders and provide opportunities to pass through the liminal period. This strong belief in diving makes it a unique thing to study further.

During the Covid 19 Pandemic, the people of Central Java consider this event as a page bulk. Every time, traditional people believe that pagebluk must happen. Pagebluk occurs because of a macrocosm imbalance with the microcosm. The macrocosm is shaken because it has experienced disharmony, either with one another or with the universe. In the realm of traditional Javanese belief, such imbalances can only be solved through selametan rituals. 
[2] The Covid 19 pandemic is a pagebluk disaster that needs to be addressed so that there is a balance between macrocosm and microcosm.

This paper will explore deeply the beliefs of traditional people in Central Java, especially related to how selametan can be trusted as a solution to the liminality of life. On the most exciting side, selametan is used by Javanese people to reconcile themselves with their environment. Traditional Javanese people of various religions make their doctrinal teachings unusable to "reconcile" society with each other. Selametan is an effective way to "reconcile" one's communities with each other when they are in the liminal phase, in conflicts between local communities.

\section{Method}

Researchers use qualitative approaches with descriptive-analytical methods as their analytical knives in unraveling and looking at diving in society. According to Sugiyono [3], descriptive research is research conducted to determine the value of independent variables, either one or more variables (independent), without making comparisons or connecting one variable with another variable. This method is used to present data thoroughly and in-depth about interpreting symbols and research objects in society. Data collection is conducted with interviews, observations with active participation. Data analysis is done by triangulating the data to validate the data presented. Depth interview is conducted to find biological data from research objects. [6]

\section{Discussion}

Victor Turner's main contribution lies in understanding religious expression in the form of a concept of the ritual ceremony process. The concept of liminality as a connecting bridge, which is unstructured, transitional, and is a level or phase without classification, reflects his view of ceremony and religion as a formative and reflective system. Through the liminality phase, the ceremony underlies a process of transformation. It simultaneously re-establishes the old categories of structural nature and serves as the driving force center for various activities to create new forms of structural concepts. [7]

Thus, the relationship between the ceremony and the social structure lies in the ability of the ceremony to be able to place itself above the position of the unit of social structure by going through the liminal phase or the anti-structural phase, so that the relationship between the ceremony and the social structure allows it to remain sustainable in the activities of the ceremony itself. In this case, the ceremony serves as a guideline for all phases and all aspects of the cultural experience through various processes passed by each individual. In other words, the ceremony is a source for the creation of new ideas that are encouraged to be revived in liminal times and a source for the realization of the status quo in its implementation. Dimensions in a ritual process according to Victor Turner [6] are:

a. Process analysis: i.e., studying the spirito-psycho-social process that occurs, the methodical aspects, and the stages (transformation phases).

b. Symbolic theory: i.e., understanding the symbolic meanings represented.

c. Structure and anti-structure: later, we will see that the ritual has a very close relationship in forming a societal structure and the deformation (conversion) of an established 
structure. Here a ritual is studied about society's structure and its function as the guardian of social order.

d. Liminal: Liminal state is a condition found in a transition/transformation, where there is disorientation, ambiguity, openness, and uncertainty (indeterminacy).

In this liminal state, changes are possible, for example, social status, personality value, or personal identity. So, in other words, liminality is a transition period in which the mind is ordinary, self-understanding, and behavior in a relaxed, open, and receptive state to accept change. [8]

The problems with which victor Turner's model has been proposed are: first, a symbolic form based on a primordial basis that seems difficult to accept, as it leaves very little room for the specificity of cultural expressions that are sourced or based on local social and economic realities, and also particularly concerning the various social and economic concepts of local people, which are shrouded in and within the scope of religious thought. Second, it also seems quite difficult to accept that the formal structure's liminal period was destructive. The symbols inside and used to define the liminal period are strictly structured and must be seen concerning other structural units, where the individual came from, and where they will return to where he came from. The nature of the liminal period is reflective and formative. This will appear more clearly when expressed using concrete transformative references derived from/or that exist in structural environments that are non-ritual or non-ceremonial. Third, the symbols only had meaning in the liminal period (i.e., after being isolated from the structural classification system). The essence of the symbolic thinking motif was organic and primordial. In this case, Turner has stated that the available source of the symbolic form and religious thought and the ceremonial act comes from the outside (when viewed with the categories and structural levels that it transforms and defines).

Thus, Turner saw that the forces that encouraged and created elements for creating a culture that gave information or information structurally, as he said came from the outside of the structure itself, gave the impression of conflict in its concepts. Supposedly, neither the mediation process nor the intermediation or the push for creation in those structures is structurally and functionally present in the system itself. Among Turner's analyses of the structure of the ceremony and its symbolic content to be examined are those relating to [7] :

a. system of dualism and triadism

b. basic physiology of symbols

c. liminality as an accommodating concept for transformation.

In essence, Turner's symbols were seen as dualistic, but "every form of dualism was filled with a broader classification model." The context of the place or position of the symbol in the ceremony determines the conceptual pattern of relating to the ceremony's symbolic system itself as a whole. The symbols in the ceremony have a meaning and are domiciled in the system of social structure. So, according to Turner, the system is triadic or triangular and flexible in context. Conceptually symbols are seen through their position in the triadic structure and can therefore be manipulated through their absence and through the nature of ambivalence, which exists and is indeed its nature, towards other symbols around it. [8]

According to Turner, the fundamental and powerful and widespread nature of the symbolic form in human life is that the symbols are derived from the nature of human origin, which he named and derived from the "primordial biological experience." [5] The organism of the human body, together with its "important and meaningful experience," serves as a kind of pattern used to create something symbolically" for the sake of communicating the content of the ceremony. Behind all of this, the most fundamental of primordial and humanitarian natures are classification systems, and which symbolically have expanded their scopes. 
Thus Turner saw that the forces that encouraged and created cultural creation elements that gave structural information or information came from the outside of the structure itself, giving the impression of conflict in his concepts. Supposedly, neither the mediation process nor the intermediation or the push for creation in those structures is structurally and functionally present in the system itself. Turner sees that ceremonies play a role in making individuals fit into their communities and allow them to accept the rules. [6] What is noteworthy in the study of the relationship between social structure and religion and ceremony is about the social and economic realities that exist in the environment faced by the perpetrators in society, so that questions relating to the relevance of a religious belief and ceremony that are seen as social structures or as patterns of relationship manifested between social structure and religion and ceremony, should not be seen in the context of the structure itself, but in a broader context and based on the real-life faced by the perpetrators concerned. This is because religion has various essential functions that manifest in different ways in human social life.

Indonesia ranks fourth as the most populous country predicted to have long-suffering exposure to the Covid-19pandemic. [8] With a vast country and population density spread across several central islands, Indonesia's State has its challenges to overcome Covid-19. Remote and disadvantaged areas also have a high risk of exposure to Covid-19 due to the difficulty of accessing health services in these areas. [8] Despite its challenges, remote areas in Indonesia usually have local wisdom with their disaster mitigation methods. Prasetyo evidences that local wisdom in traditional communities in Indonesia is an alternative in preventing disasters or in post-disaster management so that local wisdom has a vital role in mitigating disasters that occur in Indonesia so that the Government can utilize the values of local wisdom as a step in disaster mitigation in the country. The usefulness of local wisdom in disaster mitigation as a "cultural approach." [11]

One of the local wisdom used by the community in responding to disasters is selametan. Traditional Javanese people believe that selametan can do the community from disasters. Diving rituals are usually performed by elders and ritual devices that begin with the recitation of prayers and burning offerings, as a form of devotion to Gusti Kang Murbeng Durmadi. Slametan rituals performed by elders and ritual practitioners must be performed in an old place and believed to be valid. For ritual practitioners, this slametan has two meanings, namely:

First, slametan as a condition of obtaining blessings. This kind of slametan is held before the ritual performer feels the results before his wish is granted. As already said, slametan is not the only factor that, according to the perpetrator, is very important to get blessings from Gusti Kang Murbeng Dumadi. Slametan is seen as unnecessary, meaning good if done, but even if it is not okay. Second, slametan is done as a gratitude for the success or fulfillment of the pilgrim's request. Slametan can also be called thanksgiving, and the ritual practitioners usually do it because they have vowed before. Anyone who forgets his vows or promises after success will receive a warning from Gusti Kang Murbeng Dumadi in the form of a constant nightmare.

Another exciting thing about this slametan ritual is the belief of other ritual practitioners who believe that when they eat the slametan ritual dish, they will participate in blessings, and their request can be granted immediately. Another belief circulating among pilgrims is rice from the slametan ritual is believed to cure various diseases by drying first, then brewed with water to be drunk by people who have diseases. This belief makes some pilgrims and locals try to get rice from the results of slametan rituals.

During this pandemic, selametan was done to repel the outbreak and ask that the people around the region can be prevented from the outbreak. Selametan was carried out by village 
elders and requested safety from the rulers of the surrounding nature so that the plague did not pass by and stop by the local area. The most sacral place in the region is usually used as a ritual because the ruler of the territory exists and resides in it. In Turner's language, symbolic places and offerings brought by elders and ritualists became a bridge to attract attention to the rulers of the region so that they passed the community from the plague. Selametan is believed to be an effective tool for reconciling from the plague and balancing macrocosm and microcosm.

\section{Conclusion}

The Covid 19 pandemic has changed the face of the earth along with the rest of the world's population. There are no people who are not affected by the Covid 19 virus. All governments in the world are fighting against invisible viruses. Various efforts and strategies have been made to prevent the transmission of this virus. Indonesia is a country that strives to inhibit the rate of transmission. Large-scale Social Restrictions Policy cannot inhibit the rate of transmission of the virus. Even so, traditional people's efforts were made to pass the Covid 19 virus through diving rituals. Traditional people believe selametan can be done from the current outbreak. In accordance with Turner's theory, the symbols only had meaning in the liminal period (i.e., after being isolated from the structural classification system). The essence of the symbolic thought motive was organic and primordial. Traditional Javanese people believe that selametan is a symbol that is trusted and used in the liminal period, especially during the Liminality period of the Covid 19 pandemic.

\section{References}

[1] F. J. Nugroho, "Ritual Mistis di Dunia Politik: Studi pada Ritual Ngalab Berkah di Gunung Kemukus," Hanifiya J. Stud. Agama-Agama, vol. 3, no. 1, pp. 14-26, Jun. 2020, doi: 10.15575/hanifiya.v3i1.8431.

[2] C. Geertz, The Religion of Java. Chicago: University of Chicago Press, 1976.

[3] F. J. Nugroho and A. D. Rengganis, "MITIGASI EKOLOGI DI OBYEK WISATA RELIGI GUNUNG KEMUKUS," Reli. J. Stud. Agama-agama, vol. 16, no. 1, Jun. 2020, doi: 10.14421/rejusta.2020.1601-01.

[4] I. G. A. Paramita, "BENCANA, AGAMA DAN KEARIFAN LOKAL," Dharmasmrti J. Ilmu Agama dan Kebud., vol. 18, no. 1, pp. 36-44, May 2018, doi: 10.32795/ds.v1i18.100.

[5] Sugiyono, Memahami Penelitian Kualitatif. Bandung: Alfabeta, 2012.

[6] A. Hamzah, Metode Penelitian Kualitatif. Malang: Literasi Nusantara, 2020.

[7] R. Lawang and P. Johnson, Teori Sosiologi: Klasik dan Modern. Jakarta: PT. Gramedia Pustaka Utama, 1990.

[8] G. Ritzer and G. D. J, Teori Sosiologi: Dari Teori Sosiologi Klasik Sampai Perkembangan Mutakhir Teori Sosial Postmodern. Yogyakarta: Kreasi Wacana, 2010.

[9] N. Susan, Sosiologi Konflik Teori-Teori dan Analisis, 4th ed. Jakarta: Kencana, 2019.

[10] R. Djalante et al., "Review and analysis of current responses to COVID-19 in Indonesia: Period of January to March 2020," Prog. Disaster Sci., vol. 6, p. 100091, Apr. 2020, doi: 10.1016/j.pdisas.2020.100091.

[11] B. Prasetyo, "Kearifan Lokal sebagai Basis Mitigasi Bencana. Seminar Nasional FST- 
UT 2019.” pp. 111-129., 2019. 